\title{
Manufacturing Firms' Performance and Productivity: Evidence from North and South European, Scandinavian and Balkan Countries
}

\author{
Christos Lemonakis ${ }^{1}$, Konstantinos Vassakis ${ }^{2}$, Alexandros Garefalakis ${ }^{3}$, \\ Xanthi Partalidou ${ }^{4}$ \\ ${ }^{1}$ School of Business Administration, MBA Program, Neapolis University, Pafos, Cyprus \\ ${ }^{2}$ Department of Science, Technological Educational Institute of Crete, Heraklion, Greece \\ ${ }^{3}$ Department of Accounting and Finance, Technological Educational Institute of Crete, Heraklion, Greece \\ ${ }^{4}$ Department of Agricultural Development, Democritus University of Thrace, Orestiada, Greece \\ Email: c.lemonakis@nup.ac.cac.cy, kvassakis@gmail.com, alex_garefalakis@yahoo.gr, \\ partalidouxanthi@gmail.com
}

Received 25 July 2016; accepted 21 August 2016; published 24 August 2016

Copyright (C) 2016 by authors and Scientific Research Publishing Inc.

This work is licensed under the Creative Commons Attribution International License (CC BY).

http://creativecommons.org/licenses/by/4.0/

\section{(c) (i) Open Access}

\begin{abstract}
The purpose of the study is to analyze and compare the financial performance of manufacturing firms of Central and South European, Scandinavian and Balkan countries. In addition, the impact of firm's productivity on country's export intensity, foreign direct investments, R\&D activity and financing costs is examined. This is the first comparative study making an inter-country, interregional and inter-manufacturing sector comparison of the financial performance of manufacturing firms in European, Scandinavian and Balkan regions through selected countries. This research attempts to investigate the relation of macro variables, such as country export intensity, FDI and $R \& D$ on the competitiveness of the manufacturing firms in those countries measured on the firm level. In order to access the factors that affect the competitiveness of the manufacturing firms in each one of the 15 countries of the sample, we run 15 Tobit (truncated) models, using balanced panel data for the period 2008-2011.
\end{abstract}

\section{Keywords}

Manufacturing, Performance, FDI, R\&D, Competitiveness, Sales per Employee 


\section{Introduction}

The competitiveness of the economies of Balkan countries represents a strategic European interest. Wellfunctioning market economies that resistant to global competitive pressures contributing to the political stabilization of the Western Balkan region as well as to growth and jobs for Europe, which is the EU's main policy objective for the years to come. Foreign direct investment (FDI) inflows help sustain economic growth and generate employment in the formal sector, promote exports, rebalance growing trade deficits and maintain the process of economic reconstruction.

This paper makes an inter-country as well as inter-regional and inter-manufacturing sector comparison of the financial performance of manufacturing firms in European, Scandinavian and Balkan regions through selected countries. To the best of our knowledge, there is not such a comparative study so far.

Furthermore, the research attempts to investigate the relation of macro variables, such as country export intensity, FDI and R\&D on the competitiveness of the manufacturing firms in those countries measured on the firm level. In current literature, most of the published studies examine the bivariate relationship, theoretically or empirically, between economic growth and exports, economic growth and foreign direct investments or exports and foreign direct investments.

The study is structured as follows: the next section presents relevant literature, while section 3 highlights the methodology as well as the model approach of the study. In section 4, the empirical results of the study are presented and discussed. Section 5 summarizes the empirical findings and draws the policy implications of the study.

\section{Literature Review}

The inter-country as well as inter-region comparisons of firms' financial characteristics have concentrated great interest in finance. Comparing the financial performance of diverse groups of firms, [1] and [2] predict the financial performance of healthy and no-healthy firms. Reference [3] compares the overall financial characteristics of U.S. and Japanese manufacturing firms with data from 28 different industries. Reference [4] finds significant differences between the financial performance of U.S.A. and Canadian manufacturing firms. Reference [5] compares U.S., E.U., and Japanese manufacturing firms and finds that their financial performances are significantly different. Reference [6] compares the financial performance of manufacturing firms within the E.U. and concludes that, despite economic integration, the differences between the financial performances of firms in different E.U. countries persist.

$R \& D$ and innovation has recognized as key factor of firms' productivity and income gains. In the majority of the empirical studies, economic growth is significantly correlated with foreign direct investments (FDI), exports and R\&D investments. FDI inflows can play a vital role in host countries due to the fact that it increases the supply of funds for domestic investments. Furthermore, FDI inflows not only can increase the export capacity of the host country but also encourage the creation of new jobs. In addition, foreign technology transfer through imported inputs and foreign investments lead on the success of the manufacturing sector [7] (Goldberg et al., 2010).

Reference [8] supports that there exists a triangular relationship among FDI, exports and economic growth. This means that FDI has both direct and indirect effects on economic growth through exports. Reference [9] examined the Granger causality relations among GDP, exports and FDI in Middle East and North Africa (MENA) countries and found that there are bidirectional causality relations among these variables. The technology and expertise (know-how) of multinational firms seems to play vital role for international knowledge transfer. Therefore, FDI lead to significant positive spillover effects on the labor productivity of domestic firms [10].

Reference [11] investigated the relationship between exports, FDI of Greece over the period of 1960-2002. This study found that there is a long run relation and a causality relation between the examined variables. Reference [12] investigated the relationship among economic growth, exports and FDI for ten European countries over the period 1994-2008. Their study revealed that there is causality relation among FDI, exports and economic growth in four out of ten countries. Reference [13] examined the impact of substantial FDI inflows in producer service sectors on the total factor productivity of Chilean manufacturing firms and suggested that service FDI fostering innovation activities of manufacturing firms and offering opportunities for less competitive firms against industry leaders. 
Many empirical studies examined the relationship between innovation-productivity and innovation-exporting activity. The majority of the studies highlight R\&D investments as a significant determinant of firm's productivity [14], while others conclude to the positive correlation between R\&D and firm exporting activity [15]. However, there is no clear research indicating the relationship between productivity, exports, R\&D and FDI at manufacturing firm-level data.

A debate in empirical studies about the impact of exports on productivity growth, using country or industry level data, exists [16]-[18] using data from 34 countries covering the time period 1995-2006, indicated that exporters are more productive than non-exporters, while exporting does not necessarily improve productivity. In that context, [19] concluded that US manufacturing exporting firms present higher productivity levels, but they have not find evidence that export activity affects productivity growth. Reference [20] using a data sample of UK small firms concluded that firms with exporting activity (regular, irregular and new exporters) have higher productivity measured with sales per worker than non-exporters.

The study investigates at first part the financial performance of manufacturing firms in North and South European, Scandinavian and Balkan Countries and compares them in terms of size, growth, profitability, productivity, liquidity and capital intensity. Through econometric modeling, we focus on the effect of country export intensity on firm level productivity, controlled for FDI, R\&D, labor productivity and cost of financing [21].

\section{Methodology and Data}

\subsection{Data}

The study covers the period 2008-2012, taking into account the post economic crisis effects. The data sample consists of 1159 firms from sixteen (16) countries: Austria, Belgium, Denmark, France, Germany, United Kingdom (North and Central Europe region), Italy, Portugal, Spain (Southern Europe region), Finland, Norway, Sweden, (Scandinavian region) Bulgaria, Lithuania, Montenegro and Greece (Balkan region). The dataset in this study appears for the first time in order to making an inter-country, inter-regional and inter-manufacturing sector comparison between the financial performance and profile manufacturing firms in European, Scandinavian and Balkan regions. The data were taken from the Datastream database (Tables 1-3).

Table 1. Number of firms per country.

\begin{tabular}{ccc}
\hline Country & Number of Firms & Percentage \% \\
\hline Austria & 41 & $3.54 \%$ \\
Belgium & 47 & $4.06 \%$ \\
Bulgaria & 7 & $0.60 \%$ \\
Denmark & 17 & $1.47 \%$ \\
Finland & 58 & $5.00 \%$ \\
France & 181 & $15.62 \%$ \\
Germany & 242 & $20.88 \%$ \\
Greece & 88 & $7.59 \%$ \\
Italy & 69 & $5.95 \%$ \\
Lithuania & 21 & $1.81 \%$ \\
Montenegro & 84 & $7.25 \%$ \\
Norway & 28 & $2.42 \%$ \\
Portugal & 20 & $1.73 \%$ \\
Spain & 65 & $5.61 \%$ \\
Sweden & 58 & $5.00 \%$ \\
United Kingdom & 133 & $11.48 \%$ \\
\hline
\end{tabular}


Table 2. Number of firms per country.

\begin{tabular}{ccc}
\hline Regions & Countries & Number of Firms \\
\hline BALKANS & Bulgaria, Greece, Lithuania and Montenegro & 200 \\
EUROPEAN & Austria, Belgium, France, Germany, Italy, Portugal, Spain and United Kingdom & 798 \\
SCANDINAVIAN & Denmark, Finland, Norway and Sweden & 161 \\
Sum & & 1159 \\
\hline
\end{tabular}

Table 3. Number of firms per sector/region.

\begin{tabular}{ccccc}
\hline Sectors & BALKANS & EUROPEAN & SCANDINAVIAN & Number of Firms per Sector \\
\hline Automobiles and Parts & 3 & 57 & 4 & 64 \\
Beverages & 14 & 59 & 4 & 77 \\
Chemicals & 9 & 78 & 5 & 92 \\
Construction and Materials & 60 & 118 & 21 & 199 \\
Food Producers & 56 & 89 & 19 & 45 \\
Forestry and Paper & 12 & 21 & 12 & 176 \\
Industrial Engineering & 12 & 133 & 31 & 69 \\
Industrial Metals and Mining & 23 & 36 & 10 & 154 \\
Pharmaceuticals and Biotechnology & 4 & 115 & 35 & 119 \\
Technology Hardware and Equipment & 7 & 92 & 20 & 1159 \\
Total Number & 200 & 798 & 161 & 45 \\
\hline
\end{tabular}

\subsection{Units}

At first, t-test of means is used to check for differences and compare their performance. The variables are used in order to investigate the characteristics of firms in the examining regions:

- Size (total assets, total assets growth),

- Firm's growth (sales growth, total assets growth),

- Labor productivity (sales/no. of employees),

- Profitability (gross profit margin, ROA, net profit margin) [22],

- Change in machinery \& equipment,

- Inventory turnover,

- Capitalization (net fixed assets/total assets),

- Leverage (long term debt/equity) [23],

- Liquidity.

In order to access the factors that affect the competitiveness of the manufacturing firms in each one of the 15 countries of the sample, we run 15 Tobit (truncated) models, using balanced panel data for the period 2008-2011, after crisis.

The dependent variable used is a measure of productivity, sales per no of employees for each firm used as proxy for competitiveness, with independent variables macro variables: value of exports for each country, FDI and R\&D. More specifically, macro variables that are used are:

- Export value index $(2000=100)$ : Export values are the current value of exports (f.o.b.) converted to Euros and expressed as a percentage of the average for the base period (2000).

- Research and development expenditure (\% of GDP): Gross domestic expenditure on scientific research and experimental development (R\&D) expressed as a percentage of Gross Domestic Product.

- Foreign direct investment, net inflows (\% of GDP): Foreign direct investment are the net inflows of investment to acquire a lasting management interest in an enterprise operating in an economy other than that of the 
investor divided by GDP.

From the previous (Table 1), it is observed that for the post crisis period, the most profitable sectors in terms of ROA are: pharmaceuticals, food \& beverages and Industrial Engineering sectors. The highest value of Total Assets Growth was shown in Pharmaceuticals, Industrial Engineering and Construction Materials sectors. The most highly levered are Automobiles, Beverages and Chemicals. All sectors show negative net fixed assets formation [24]. The most productive in terms of labor are forestry and paper, food products and automobiles (Table 4).

$$
\alpha+\beta=x .
$$

Note that from Table 2, it is concluded that:

1) The highest sales growth was in Pharmaceuticals, Industrial Metals and Food industry,

Table 4. Descriptive statistics by sector.

(a)

\begin{tabular}{|c|c|c|c|c|c|}
\hline Sectors & $\begin{array}{l}\text { Return on Assets } \\
\text { (\%) }\end{array}$ & $\begin{array}{l}\text { Total Assets } \\
\text { Growth (\%) }\end{array}$ & $\begin{array}{c}\text { Long Term } \\
\text { Debt/Equity (\%) }\end{array}$ & $\begin{array}{c}\text { Change in Machinery \& } \\
\text { Equipment (\%) }\end{array}$ & $\begin{array}{c}\text { Sales per Employee in } \\
\text { Euros }\end{array}$ \\
\hline Automobiles and Parts & 1.43 & 2.05 & 103.70 & -6.45 & 741.65 \\
\hline Beverages & 2.92 & 1.03 & 119.60 & -4.25 & 387.06 \\
\hline Chemicals & 0.31 & 1.34 & 90.58 & -8.27 & 491.67 \\
\hline $\begin{array}{l}\text { Construction and } \\
\text { Materials }\end{array}$ & 2.37 & 6.94 & 82.87 & -5.23 & 367.07 \\
\hline Food Producers & 3.04 & 3.77 & 84.09 & -7.85 & 893.26 \\
\hline Forestry and Paper & 2.85 & -0.58 & 69.24 & -4.09 & 2392.77 \\
\hline Industrial Engineering & 4.04 & 11.55 & 49.00 & -8.20 & 347.62 \\
\hline $\begin{array}{c}\text { Industrial Metals and } \\
\text { Mining }\end{array}$ & 0.98 & 2.83 & 49.86 & -11.06 & 619.63 \\
\hline $\begin{array}{l}\text { Pharmaceuticals and } \\
\text { Biotechnology }\end{array}$ & 13.10 & 15.77 & 59.95 & -8.09 & 543.23 \\
\hline $\begin{array}{l}\text { Technology Hardware } \\
\text { and Equipment }\end{array}$ & 2.04 & 6.28 & 36.01 & $-2.84 \%$ & 733.70 \\
\hline
\end{tabular}

(b)

\begin{tabular}{|c|c|c|c|c|c|}
\hline Sectors & Liquidity & $\begin{array}{c}\text { Sales Growth } \\
\text { (\%) }\end{array}$ & $\begin{array}{l}\text { Net Fixed Assets/Total } \\
\text { Assets (\%) }\end{array}$ & $\begin{array}{c}\text { Gross Profit Margin } \\
\text { Growth (\%) }\end{array}$ & $\begin{array}{l}\text { Property, Plant, Equipment } \\
\text { (PPE) Growth (\%) }\end{array}$ \\
\hline Automobiles and Parts & 1.04 & 6.35 & 25.15 & 9.68 & 5.41 \\
\hline Beverages & 0.81 & 5.14 & 31.42 & 13.13 & 1.03 \\
\hline Chemicals & 1.96 & 8.96 & 30.59 & 5.79 & 3.74 \\
\hline Construction and Materials & 1.24 & 0.62 & 29.48 & 1.57 & 0.83 \\
\hline Food Producers & 2.36 & 10.10 & 31.81 & 2.87 & 5.52 \\
\hline Forestry and Paper & 1.43 & 6.97 & 51.40 & 12.61 & 2.07 \\
\hline Industrial Engineering & 2.26 & 4.27 & 20.30 & 3.83 & 5.56 \\
\hline Industrial Metals and Mining & 5.01 & 21.04 & 34.24 & -3.52 & 12.35 \\
\hline $\begin{array}{l}\text { Pharmaceuticals and } \\
\text { Biotechnology }\end{array}$ & 5.30 & 39.13 & 12.79 & 15.00 & 8.31 \\
\hline $\begin{array}{c}\text { Technology Hardware and } \\
\text { Equipment }\end{array}$ & 1.92 & 7.59 & 12.90 & 27.11 & 7.43 \\
\hline
\end{tabular}


2) The highest capitalization in Fixed Assets is in Forestry and paper, Industrial metals, Food and Beverages and Metals,

3) The highest gross profit margin was realized in the sectors of Technology Equipment, Pharmaceuticals, Beverages and Forestry-Paper,

4) Investment in new equipment and machinery, a proxy for new technology application was noticed in the sectors of Ind. Metals, Pharmaceuticals and Technology Equipment, the ones with high capitalization.

\section{Results and Discussions}

In Table 5 and Table 6, the performance characteristics of manufacturing firms per region are presented. The results can issue significant indicators about the differences between the financial characteristics of manufacturing firms of Balkan, European and Scandinavian countries.

Scandinavian firms are the largest and present the highest profitability among others. European firms exhibited the highest Total Assets growth and have the highest inventory efficiency, while Balkan countries have the mostly heavily levered firms. Scandinavian firms are the ones with the highest labor productivity [25].

European and Scandinavian countries show adequate interest coverage ratios and liquidity. Scandinavian firms show no to be affected by the economic crisis with $22.2 \%$ average annual sales growth rate. European firms follow with a $10 \%$ rate while Balkan firms seem to be hit by the crisis with a negative growth rate of $-1.15 \%$. Gross profit margin growth rate is around 10\% for both European and Scandinavian countries and only 1.35\% for the Balkan manufacture. Scandinavian firms showed the highest investments in Net Fixed Assets.

Table 5. Descriptive statistics per region (average).

(a)

\begin{tabular}{|c|c|c|c|c|c|c|c|}
\hline Regions & $\begin{array}{c}\text { Return on } \\
\text { Assets (ROA) }\end{array}$ & $\begin{array}{l}\text { Total Assets } \\
\text { (Average) }\end{array}$ & $\begin{array}{l}\text { Total Assets } \\
\text { Growth }\end{array}$ & $\begin{array}{c}\text { Total Debt/Equity } \\
\text { (\%) }\end{array}$ & $\begin{array}{l}\text { Change in Machinery } \\
\text { \& Equipment (\%) }\end{array}$ & $\begin{array}{l}\text { Inventory } \\
\text { turnover }\end{array}$ & $\begin{array}{l}\text { Sales per } \\
\text { Employee }\end{array}$ \\
\hline BALKANS (BALK) & $-37.80 \%$ & $320,121.61$ & $-3.07 \%$ & 152.69 & -1.58 & 28.92342 & 288.77 \\
\hline EUROPEAN (EUR) & $10.62 \%$ & $4,627,769.52$ & $22.70 \%$ & 104.37 & -7.35 & 39.07034 & 435.35 \\
\hline $\begin{array}{l}\text { SCANDINAVIAN } \\
\text { (SCAND) }\end{array}$ & $30.12 \%$ & $15,342,688.1$ & $13.84 \%$ & 86.96 & -6.09 & 17.05426 & 1562.27 \\
\hline t-test & 1.9612 & 2.9856 & -7.1854 & $19.7918^{*}$ & \multirow{2}{*}{$-1.0275(0.0679)$} & 0.5987 & $1.6985^{* *}$ \\
\hline (BALK-EUR) & $(0.0067)^{*}$ & $(0.0007)^{*}$ & $(0.0000)^{*}$ & $(0.0000)$ & & (1.0615) & $(0.0486)$ \\
\hline t-test & 1.9617 & 2.527 & 4.5638 & $1.9275^{* *}$ & \multirow{2}{*}{$-1.0074(0.0771)$} & 0.3708 & $15.9476^{*}$ \\
\hline (BALK-SCAND) & $(0.0261)^{* *}$ & $(0.00000)^{*}$ & $(0.0005)^{*}$ & $(0.0339)$ & & $(0.7107)$ & $(0.0000)$ \\
\hline
\end{tabular}

Pairwise t-test, $\mathrm{p}$ values in parenthesis. $\left(^{*}\right),\left({ }^{* *}\right)$ significance at $1 \%, 5 \%$ respectively.

(b)

\begin{tabular}{|c|c|c|c|c|c|c|}
\hline REGIONS & $\begin{array}{l}\text { Operating Expenses } \\
\text { in Euros }\end{array}$ & $\begin{array}{l}\text { Earnings Before Interest and } \\
\text { Taxes (EBIT)/Total } \\
\text { Interest Expenses }\end{array}$ & $\begin{array}{l}\text { Quick } \\
\text { Ratio }\end{array}$ & $\begin{array}{l}\text { Sales } \\
\text { Growth }\end{array}$ & $\begin{array}{l}\text { Gross Profit } \\
\text { Margin-Growth }\end{array}$ & $\begin{array}{l}\text { Property, Plant, } \\
\text { Equipment (PPE) } \\
\text { Growth }\end{array}$ \\
\hline BALKANS (BALK) & 296,809 & 0.936 & 0.9859 & $-1.15 \%$ & $1.35 \%$ & $-1.08 \%$ \\
\hline EUROPEAN (EUR) & $3,590,093$ & 3.559 & 2.8505 & $10.83 \%$ & $9.95 \%$ & $5.19 \%$ \\
\hline $\begin{array}{l}\text { SCANDIVIAN } \\
\text { (SCAND) }\end{array}$ & $14,006,537$ & 4.002 & 1.8676 & $22.21 \%$ & $8.11 \%$ & $10.32 \%$ \\
\hline $\begin{array}{c}\text { t-test } \\
\text { (BALK-EUR) }\end{array}$ & $\begin{array}{l}3.988^{*} \\
(0.0000)\end{array}$ & $\begin{array}{l}4.9282^{*} \\
(0.0000)\end{array}$ & $\begin{array}{l}2.818^{*} \\
(0.0000)\end{array}$ & $\begin{array}{l}-4.655^{*} \\
(0.0000)\end{array}$ & $5.415^{*}(0.0000)$ & $-2.336^{*}(0.002)$ \\
\hline $\begin{array}{c}\text { t-test } \\
\text { (BALK-SCAND) }\end{array}$ & $\begin{array}{l}24.9276^{*} \\
(0.0000)\end{array}$ & $5.5236^{*}(0.0000)$ & $\begin{array}{l}2.1927^{* *} \\
(0.0211)\end{array}$ & $\begin{array}{l}8.2212^{*} \\
(0.0000)\end{array}$ & $5.1212^{*}(0.0000)$ & $3.3356^{*}(0.0000)$ \\
\hline
\end{tabular}

Pairwise t-test, p values in parenthesis. $\left(^{*}\right),\left(^{* *}\right)$ significance at $1 \%, 5 \%$ respectively. 
Table 6. Tobit regression results.

\begin{tabular}{|c|c|c|c|c|}
\hline Region & Constant & Export Value Index & $\begin{array}{l}\text { R\&D expenditure } \\
\text { (\% of GDP) }\end{array}$ & $\begin{array}{l}\text { FDI, Net Inflows } \\
\text { (\% of GDP) }\end{array}$ \\
\hline \multirow{2}{*}{ Austria } & 0.5058 & 0.27 & 47.28 & 0.17 \\
\hline & $(0.013)^{* *}$ & $(0.0329)^{* *}$ & $(0.0000)^{*}$ & $(0.0086)^{*}$ \\
\hline \multirow{2}{*}{ Belgium } & 42.04 & 0.72 & 0.45 & 3.55 \\
\hline & $(0.020)^{* *}$ & $(0.0130)^{* *}$ & $(0.008)^{*}$ & $(0.007)^{*}$ \\
\hline \multirow{2}{*}{ Bulgaria } & 21.63 & 5.71 & 0.25 & 3.85 \\
\hline & $(0.0800)$ & $(0.046)^{* *}$ & $(0.085)$ & $(0.032)^{* *}$ \\
\hline \multirow{2}{*}{ Denmark } & 74.82 & 8.03 & 10.55 & 3.67 \\
\hline & $(0.017)^{* *}$ & $(0.19)$ & $(0.0052)^{*}$ & $(0.045)^{* *}$ \\
\hline \multirow{2}{*}{ Finland } & 80.67 & 3.33 & 4.20 & 8.26 \\
\hline & $(0.0004)^{*}$ & $(0.080)$ & $(0.038)^{* *}$ & $(0.0075)^{*}$ \\
\hline \multirow{2}{*}{ France } & 15.9 & 0.66 & 8.11 & 3.59 \\
\hline & $(0.0000)^{*}$ & $(0.067)$ & $(0.0003)^{*}$ & $(0.0001)^{*}$ \\
\hline \multirow{2}{*}{ Germany } & 23.04 & 0.546 & 10.23 & 10.72 \\
\hline & $(0.0034)^{*}$ & $(0.0064)^{*}$ & $(0.0000)^{*}$ & $(0.000)^{*}$ \\
\hline \multirow{2}{*}{ Greece } & 10.65 & 0.95 & 0.22 & 8.01 \\
\hline & $(0.0000)^{*}$ & $(0.58)$ & $(0.18)$ & $(0.0056)^{*}$ \\
\hline \multirow{2}{*}{ Italy } & 78.1 & 2.26 & 0.025 & 10.85 \\
\hline & $(0.0040)^{*}$ & $(0.0039)^{*}$ & $(0.0001)^{*}$ & $(0.0036)^{*}$ \\
\hline \multirow{2}{*}{ Lithuania } & 18.24 & 2.06 & 0.04 & 21.12 \\
\hline & $(0.0000)^{*}$ & $(0.70)$ & $(0.003)^{*}$ & $(0.0000)^{* *}$ \\
\hline \multirow{2}{*}{ Norway } & 98.23 & 1.06 & 10.05 & 5.12 \\
\hline & $(0.0000)^{*}$ & $(0.060)$ & $(0.002)^{*}$ & $(0.0042)^{*}$ \\
\hline \multirow{2}{*}{ Portugal } & 8.23 & 1.89 & 0.24 & 1.12 \\
\hline & $(0.0000)^{*}$ & $(0.53)$ & $(0.02)^{*}$ & $(0.42)$ \\
\hline \multirow{2}{*}{ Spain } & 98.23 & 1.06 & 7.05 & 10.25 \\
\hline & $(0.00)^{*}$ & $(0.53)$ & $(0.002)^{*}$ & $(0.052)^{* *}$ \\
\hline \multirow{2}{*}{ Sweden } & 58.38 & 110.8 & 11.2 & 80.63 \\
\hline & $(0.0000)^{*}$ & $(0.0048)^{*}$ & $(0.0015)^{*}$ & $(0.0000)^{*}$ \\
\hline \multirow{2}{*}{ United Kingdom } & 25.6 & 40.03 & 40.73 & 10.79 \\
\hline & $(0.0000)^{*}$ & $(0.0008)^{*}$ & $(0.0000)^{*}$ & $(0.021)^{*}$ \\
\hline
\end{tabular}

Notes: ${ }^{*},{ }^{* *}$ statistical significance at $1 \%, 5 \%$ level respectively (prob. of t-stats in parenthesis). Dependent variable: sales per number of employee, a proxy for competitiveness.

There are many definitions of competitiveness but no agreement on it. The definition may range from the ability to compete, to the capacity of ensuring high profitability, or the aptitude to gain market shares. If a firm is operationally efficient, cost effective and quality conscious, it can provide customers with more value and satisfaction and thus be competitive [26] [27]. 
According to Reference [28], resource based approach, the most commonly used indicators of competitiveness of a firm are operating performance, market performance and profitability. According to Reference [29], competitiveness in the manufacturing sector is the ability to gain sustainable profits and maintain market share. In most studies, profitability, efficiency or productivity are used as proxies for competitiveness. In the present study, we use the ratio of sales over number of employees, a measure of productivity, as a proxy for competitiveness [30].

The findings suggest that for all countries except of Greece and Bulgaria, R\&D came as a significant determinant of firm level competitiveness. It is especially important for Austria and UK (Due to the lack of data we didn't insert Montenegro's firms in the econometric model, for consistency reasons). FDI is a significant determinant too for all countries at 1\% and 5\% level of significance, but more critical for Sweden and Lithuania, as indicated by their high coefficient. Export activity is an indication of firm competitiveness but only for Austria, Belgium, Bulgaria, Germany, Italy, Sweden and UK.

\section{Concluding Observations/Policy Implications}

The present empirical research suggests that the Scandinavian manufacturing firms are the most dynamic in terms of growth, have the best financial performance and do not show to have been hit by the economic crisis. European firms are in between with Balkan firms showing the worst performance as expected. After 2010, European and Scandinavian firms show an improvement in their profitability, while Balkan countries present significant reduction.

The largest manufacturing firms are in the Scandinavian countries and the smallest in the Balkans with European firms falling in between. European firms are the most effective in the management of their inventories as a strategy to overcome financing problems, thus achieving a high liquidity. Labor productivity is the highest in the Scandinavian countries. This can be explained by the size of the firms and the capital intensity and use of new technology (highest net fixed asset growth). R\&D, FDI and export intensity were found to affect positively and significantly the competitiveness of manufacturing firms in the examined countries, measured in terms of labor productivity. Availability of low cost financing, R\&D, innovation, FDI and labor productivity should be supported by policy makers.

The development of technological and R\&D cooperation among European, Scandinavian and Balkan manufacturing firms is also suggested for a convergence of financial performance and growth of their manufacture. In addition, a separation of the North and South European countries and Greece with a comparative analysis of their firms’ performance can be also included.

\section{References}

[1] Dambolena, I.G. and Khoury, S.J. (1980) Ratio Stability and Corporate Failure. Journal of Finance, 35, $1017-1026$. http://dx.doi.org/10.1111/j.1540-6261.1980.tb03517.x

[2] Chi, L.C. and Tang, T.C. (2006) Bankruptcy Prediction: Application of Logit Analysis in Export Credit Risks. Australian Journal of Management, 31, 17-27. http://dx.doi.org/10.1177/031289620603100102

[3] Meric, I., Gishlick, H.E., Taga, L. and Meric, G. (2003) A Comparison of the Financial Characteristics of U.S. and Canadian Manufacturing Firms. Midwestern Business and Economic Review, 31, 25-33.

[4] Meric, I. and Meric, G. (1994) A Comparison of the Financial Characteristics of U.S. and Japanese Manufacturing Firms. Global Finance Journal, 5, 205-218. http://dx.doi.org/10.1016/1044-0283(94)90004-3

[5] Meric, I., Weidman, S., Welsh, C. and Meric, G. (2002) A Comparison of the Financial Characteristics of U.S., EU, and Japanese Manufacturing Firms. American Business Review, 20, 119-125.

[6] Meric, I., Prober, L., Eichhorn, B. and Meric, G. (2004) Integration and the Financial Characteristics of Manufacturing Firms in the European Union. American Business Review, 22, 88-97.

[7] Goldberg, P., Khandelwal, A., Pavcnik, N. and Topalova, P. (2010) Imported Intermediate Inputs and Domestic Product Growth: Evidence from India. Quarterly Journal of Economics, 125, 1725-1765. http://dx.doi.org/10.1162/qjec.2010.125.4.1727

[8] Hsiao, F.S.T. and M.C.W. Hsiao (2006) FDI, Exports and GDP in East and Southeast Asia-Panel Data versus TimeSeries Causality Analyses. Journal of Asian Economics, 17, 1082-1106. http://dx.doi.org/10.1016/j.asieco.2006.09.011

[9] Ahmadi, R. and Ghanbarzadeh, M. (2011) FDI, Exports and Economic Growth: Evidence from Mena Region. Middle-East Journal of Scientific Research, 10, 174-182. 
[10] Blomstoerm, M. and Persson, H. (1983) Foreign Investment and Spillover Efficiency in an Underdeveloped Economy. Evidence from the Mexican Manufacturing Industry. World Development, 11, 493-501. http://dx.doi.org/10.1016/0305-750X(83)90016-5

[11] Dritsaki, M., Dritsaki, C. and Adamopoulos, A. (2004) A Causal Relationship between Trade, Foreign Direct Investment and Economic Growth for Greece. American Journal of Applied Sciences, 1, 230-235. http://dx.doi.org/10.3844/ajassp.2004.230.235

[12] Acaravci, A. and Ozturk, I. (2012) Foreign Direct Investment, Export and Economic Growth: Empirical Evidence from New EU Countries. Journal for Economic Forecasting, 2, 52-67.

[13] Fernandes, A.M. and Paunov, C. (2012) Foreign Direct Investment in Services and Manufacturing Productivity: Evidence for Chile. Journal of Development Economics, 97, 305-321. http://dx.doi.org/10.1016/j.jdeveco.2011.02.004

[14] Griffith, R., Huergo, E., Mairesse, J. and Peters, B. (2006) Innovation and Productivity across Four European Countries. Oxford Review of Economic Policy, 22, 483-498. http://dx.doi.org/10.1093/oxrep/gri028

[15] Lemonakis, C., Vassakis, K. and Voulgaris, F. (2013) Innovation and Manufacturing Exports: The Case of Greek Firms. Journal of Computational Optimization in Economics and Finance, 5, 95-107.

[16] Giles, J.A. and Williams, C.L. (2000) Export-Led Growth: A Survey of the Empirical Literature and Some NonCausality Results, Part I. Journal of International Trade \& Economic Development, 9, 261-337. http://dx.doi.org/10.1080/09638190050086177

[17] López, R.A. (2005) Trade and Growth: Reconciling the Macroeconomic and Microeconomic Evidence. Journal of Economic Surveys, 19, 623-48. http://dx.doi.org/10.1111/j.0950-0804.2005.00264.x

[18] Wagner, J. (2007) Exports and Productivity: A Survey of the Evidence from Firm-Level Data. World Economy, 30, 6082. http://dx.doi.org/10.1111/j.1467-9701.2007.00872.x

[19] Bernard, A.B. and Jensen, J.B. (2004) Exporting and Productivity in the USA. Oxford Review of Economic Policy, 20, 343-357. http://dx.doi.org/10.1093/oxrep/grh020

[20] Requena Silvente, F. (2005) Changing Export Status and Firm Performance: Evidence from UK Small Firms. Applied Economics Letters, 12, 567-571. http://dx.doi.org/10.1080/13504850500120649

[21] Garefalakis, A., Dimitras, A., Lemonakis, C. and Floros, C. (2016) How Narrative Information Changed the Business World: Providing a New Measurement Tool. Corporate Ownership and Control, 13, 317-334.

[22] Kim, H. and Gu, Z. (2006) Predicting Restaurant Bankruptcy: A Logit Model in Comparison with a Discriminant Model. Journal of Hospitality and Tourism Research, 30, 474-493. http://dx.doi.org/10.1177/1096348006290114

[23] Peteraf, M.A. (1993) The Cornerstones of Competitive Advantage: A Resource-Based View. Strategic Management Journal, 14, 179-191. http://dx.doi.org/10.1002/smj.4250140303

[24] Garefalakis, A., Lappa, E., Mantalis, G., Xanthos, G. and Alexopoulos, G. (2015) Is the Adoption of IFRS, an Essential Element Concerning the Mediterranean European Union’s Banks? European Journal of Scientific Research, 136, 169177.

[25] Sariannidis, N., Giannarakis, G., Litinas, N. and Konteos, G. (2010) A GARCH Examination of Macroeconomic Effects on US Stock Market: A Distinguish between the Total Market Index and the Sustainability Index. European Research Studies, 13, 129-142.

[26] Johnson, H.T. (1992) Relevance Regained. The Free Press, New York.

[27] Hammer, M. and Champy, J. (1993) Re-Engineering the Corporation. Harper Business, New York.

[28] Sariannidis, N., Zafeiriou, E., Giannarakis, G. and Arabatzis, G. (2012) CO2 Emissions and Financial Performance of Socially Responsible Firms: An Empirical Survey. Business Strategy and the Environment, 22, 109-120. http://dx.doi.org/10.1002/bse.1737

[29] Fischer, C. and Schornberg, S. (2007) Assessing the Competitiveness situatIon of EU Food and Drink Manufacturing Industries: An Index-Based Approach. Agribusiness, 23, 473-495. http://dx.doi.org/10.1002/agr.20139

[30] Drimbetas, E., Sariannidis, N., Giannarakis, G. and Litinas, N. (2010) The Effects of Macroeconomic Factor on the Sustainability, Large-Cap and Mid-Cap Dow Jones Indexes. International Journal of Business Policy and Economics, 3, 21-36. 


\section{Submit or recommend next manuscript to SCIRP and we will provide best service for you:}

Accepting pre-submission inquiries through Email, Facebook, LinkedIn, Twitter, etc.

A wide selection of journals (inclusive of 9 subjects, more than 200 journals)

Providing 24-hour high-quality service

User-friendly online submission system

Fair and swift peer-review system

Efficient typesetting and proofreading procedure

Display of the result of downloads and visits, as well as the number of cited articles

Maximum dissemination of your research work

Submit your manuscript at: http://papersubmission.scirp.org/ 